\title{
Amount, distance-dependent and structural effects of forest patches on bees in agricultural landscapes
}

\author{
Ehsan Rahimi ${ }^{*} \mathbb{B}$, Shahindokht Barghjelveh ${ }^{1}$ and Pinliang Dong ${ }^{2}$
}

\begin{abstract}
Background: The growing human population and the need for more food in the world have reduced forests and turned them into agricultural land. Many agricultural products are dependent on pollinating bees, so it is possible to increase crop production by increasing the population of bees in agricultural landscapes and preventing further deforestation. In agricultural landscapes, bees use forest patches as nesting habitats and, therefore, are highly dependent on these patches. Therefore, by creating new forest patches within agricultural fields, we can increase the pollination rate, and thus the crop production. In this regard, understanding the role of forest patches and their effects on bee populations is a key step in successfully implementing the patch creation strategy. To determine the effects of forest patches on bees and pollination services, we reviewed 93 articles examining the effects of forest patches on bees in agricultural landscapes. We divided these effects into three categories based on the sampling method: (1) distance-dependent, (2) amount, and (3) structural effects.

Methods: We searched for published studies related to the effects of the forest patches on bees in agricultural landscapes using the ISI Web of Science. We conducted our search from May 1991 to May 2021 using the following search string keywords: forest fragment, forest patch, forest fragmentation, pollination, and bee.

Results: Approximately, $79 \%$ of studies showed that by increasing the distance (up to $2 \mathrm{~km}$ ) from forest patches, regardless of the type of species, the type of agricultural product around the patches, the size and number of patches, the bees' diversity and abundance decrease. Approximately, $76 \%$ of the studies showed that the presence of forest cover within a radius of $2 \mathrm{~km}$ from the target sites has a positive effect on bee populations. Our data also show that larger forest patches maintain a larger population of bees than smaller ones.
\end{abstract}

Conclusion: It was not clear what percentage of a landscape should be covered by forest or how much habitat was sufficient to maintain a viable population of bees. Therefore, we suggest future studies to find the thresholds of forest amounts below which the bee population is rapidly declining.

Keywords: Agricultural landscapes, Bees, Forest patches, Pollination

*Correspondence: e rahimi@sbu.ac.ir; ehsanrahimi666@gmail.com 1 Environmental Sciences Research Institute, Shahid Beheshti University, Tehran, Iran

Full list of author information is available at the end of the article

\section{Introduction}

In recent years, declining pollinator populations as a global concern [123] have led to more research into identifying their threats and the consequences of their reduction in natural and agricultural systems. Approximately, $88 \%$ of angiosperms [81] and 87 of the 115 most important food products require pollinators [57]. Klein et al. [57] claim that at least $35 \%$ of the world's food products original author(s) and the source, provide a link to the Creative Commons licence, and indicate if changes were made. The images or other third party material in this article are included in the article's Creative Commons licence, unless indicated otherwise in a credit line to the material. If material is not included in the article's Creative Commons licence and your intended use is not permitted by statutory regulation or exceeds the permitted use, you will need to obtain permission directly from the copyright holder. To view a copy of this licence, visit http://creativecommons.org/licenses/by/4.0/. The Creative Commons Public Domain Dedication waiver (http://creativecommons.org/publicdomain/zero/1.0/) applies to the data made available in this article, unless otherwise stated in a credit line to the data. 
are directly dependent on pollinators, and therefore these species are of considerable economic importance. Among pollinator species, bees are known as the most important pollinators [127]. Farmers often use honeybees to pollinate their agricultural products but recent declines in the population of these species [87] have led to more attention being paid to wild bees. In the absence of honeybees, wild bees can increase agricultural products by pollination [43]. Wild bees account for $9.5 \%$ of the total agricultural products in the world [41].

Due to the growing human population, it is necessary to increase agricultural production by $70 \%$ by 2050 [21]. The second goal of the Sustainable Development Goals (SDGs) is improving nutrition and promoting sustainable agriculture for achieving food security and consequently ending hunger [6]. These goals would need more arable land in agricultural landscapes which may lead to the deforestation process [54]. Agricultural production is not only dependent on soil fertility, water quality, and pest regulation but also is related to biodiversity such as the presence of pollinators in agricultural farms [11]. Crop pollination by bees is one of the well-recognized ecosystem services in agricultural landscapes, which plays a key role in global food production $[9,88]$. Therefore, we can improve production per unit area through increasing pollination rather than expanding agricultural land.

Recent declines in the honeybee population, along with increasing demand for pollination services in urban, agricultural, and natural environments, have led to strategies to increase and attract pollinators to these areas. Creating new natural patches in suitable places can increase ecosystem services in a landscape [37]. In landscapes that experienced drastic changes and the remaining habitats are highly fragmented, creating new habitat patches can provide a new habitat alongside the remaining patches [29]. For example, restoring a forest habitat to make a connection between the remaining patches improves functional diversity [28]. To increase pollination in agricultural landscapes which consist of two ecosystems, agriculture and forest, it is critical to understand how wild bees are affected by habitat quality and landscape structure $[83,116]$. Investigating the effects of forest fragmentation on pollination can be a useful guide in optimizing a landscape to increase pollination service [70].

The presence of nesting habitat and floral resources is of great importance for bees. [83, 94]. Moreover, the proximity of these habitats to each other provides favorable conditions for pollinators because they spend less energy to find food and take it to the nest [60]. Therefore, the distance between nesting habitat and feeding has a significant effect on the presence of pollinators in a land landscape $[34,94,112]$. Therefore, in the study of pollinators, special attention should be paid to the structural patterns of the landscape $[91,116]$. The arrangement of suitable nesting patches and the ability of pollinators to move from these patches to surrounding farms affect the pollination rate in agricultural landscapes [74]. In addition to nesting habitat, adequate floral resources should be available to pollinators in a landscape [60]

In agricultural landscapes, pollination service depends on the movement of pollinators from nesting habitats (such as forests) to foraging habitats (such as farms) [94]. In these landscapes, forest fragments mostly serve as nesting habitats for bees, especially above-ground nesting species. About $30 \%$ of the more than 20,000 known bee species in the world are above-ground nesting [40]. For example, bumblebees, honeybees, and stingless bees are eusocial and are among the above-ground nesting bees [8]. Stingless bees are the most diverse social bees, and many of them depend on natural cavities to form colonies [104]. In natural environments such as forests, they nest in tree hollows. Since wild bees are highly dependent on forest patches as a nesting habitat in agricultural landscapes [83, 92], it is possible to attract more populations from pollinators by creating new forest patches. How many patches are needed and how they should be arranged in a landscape is the most important question in this area [20]. However, little attention has been paid to the location and size of the new patches, and more studies are needed in this area [73]. Therefore, it is necessary to determine the role of forest patches and their effects on bee populations in agricultural landscapes. Other important questions in this regard are (1) how do the structural aspects of forest patches, including the number, area, shape, isolation, and connectivity, affect the population of bees? (2) How far can forest patches supply pollination services by supporting bee populations? The present study aims to find answers to the mentioned questions based on previous studies. We reviewed 93 articles examining the effects of forest patches on bee populations and pollination services and presented the key results and details of these studies in three separate tables.

\section{Methods}

We searched for published studies using the ISI Web of Science. We conducted our search from May 1991 to May 2021 using the following search string: (forest fragment* OR forest patch* OR forest fragmentation*) AND (pollination* OR bee*). Nearly, 1865 articles were obtained, leaving 797 unique articles after removing duplicate articles. We were looking for studies that examined the effects of forest patches on bees in agricultural landscapes. In other words, the landscape around the forest patches was covered mostly by farms. 
We found 100 articles examining the different effects of forest patches on bees in agricultural landscapes. We divided these effects into three categories based on the sampling method: (1) distance-dependent effects: this group of studies answers the question of what changes in bee population occur with increasing distance from forest patches in the agricultural landscapes. The sampling method of bees in these studies is based on plots or transects that examine bees in the farms under study at different distances from forest patches. The first sampling site is near the forest and the last site is at the farthest distance from the forest, (2) effects of forest amount: these studies answer the question of how the amount of forest cover around the target sites affects the bee population. In this type of study, bee populations are examined in several plots and then their relationship to the forest amount around the plots is evaluated in different buffers or scales, and (3) structural effects of forest patches: in this type of study, plots or transects are placed inside forest patches (not on farms). One or more forest patches are sampled and the relationship of the bee population within these patches with the structural features of the patches such as isolation, connectivity, number, area, shape, and complexity of patches is evaluated. Details of the studies of each of the mentioned categories are presented in three separate tables, which contain 36,32 , and 33 articles (93 unique), respectively.

\section{Results}

\section{Distance-dependent effects of forest fragments on bees}

Table 1 shows the country, the number of forest patches (NP), their area (ha), the distance of sampling sites or plots from forest patches (proximity), type of pollinators, matrix around the patches, and key results of studies that have examined the distance-dependent effects of forest patches on bees' populations. This table presents 36 articles, most of which (22\%) have been conducted in Brazil. Some of these studies have reported the number of forest patches and their area in landscapes understudy, but most of them did not provide details of forest patches, so we used a dash as a lack of information. The number of forest fragments reported in these studies varies from 1 to 14 (on average 4 patches). The area of these fragments varies from 0.3 hectares to 65,000 hectares, with an average of 3100 hectares.

The proximity column shows the distance between the plots or sampling sites and forest patches. Some studies have considered only one distance, but others have examined several distances. In the proximity column, we have reported the nearest and farthest distance between the sites and forest patches. Therefore, in this column, the first number indicates the distance that the first site was examined and the second number indicates the farthest distance. These distances vary from 0 to $30 \mathrm{~km}$ of forest patches, with an average of $1900 \mathrm{~m}$. Approximately 83\% of these studies consider the maximum distance from forest fragments to be less than $2 \mathrm{~km}$. Some studies have not presented the details of the understudy species. However, social bees such as honeybees, bumblebees, and stingless bees are seen in $54 \%$ of these studies. For studies that have identified a large number of native species, we used the term "Native bees", which includes all species except honeybees. The matrix column shows the land cover around forest patches, of which $27 \%$ of the studies have examined landscapes with a matrix covered by coffee products.

Our data show that $75 \%$ of studies emphasized the positive effects of forest patches on pollinating bees at all distances. In other words, $75 \%$ of studies, regardless of the number and area of patches, the type of species, and the landscape matrix, have found that by increasing the distance from forest patches in agricultural landscapes, factors such as species richness and abundance, species diversity, pollen deposition, visitation rate, agricultural production, pollination success, and pollinator specialization decrease. However, $15 \%$ of total studies found that with increasing distance from forest fragments, species richness and abundance, and $\beta$-diversity increased, and factors such as parasitism, and mortality rate at the margins of forest patches increased. Approximately, 9\% of studies have found no relationship between forest patches and bees. In the case of honeybees, the results of some studies are inconsistent. For example, some studies have suggested that honeybee populations decrease with increasing distance from forest patches $[25,77,100]$. However, Brosi et al. [19] found that at the forest edges, honeybees made up only $5 \%$ of the individuals sampled whereas away from forests, they increased to $45 \%$. BravoMonroy et al. [14] also showed that in samples far from the forest, honeybee abundance decreased significantly.

\section{Effects of the forest amount on bees}

Table 2 shows the details of studies that have examined the effects of forest cover around plots or sampling sites on bees. This table details 33 articles, $27 \%$ of which were conducted in Brazil, which has the highest percentage compared to other countries. The buffer column shows the radius $(\mathrm{m})$ around sampling sites. Some studies have considered only one scale (buffer) while others have considered multiple scales. In studies performed on multiple scales, the first number of each row in the buffer column shows the first scale and the second number shows the maximum radius studied. The radius around the sample sites varies from $25 \mathrm{~m}$ to $15 \mathrm{~km}$ in the studies reviewed in the present study with an average of $1350 \mathrm{~m}$. Approximately, $75 \%$ of these studies consider the maximum 
Table 1 Country, number (NP) and area (ha) of forest patches, proximity to the patches (m), type of pollinators, matrix around forest patches, and key results of studies that have investigated the distance-dependent effects of forest patches on bees

\begin{tabular}{|c|c|c|c|c|c|c|c|}
\hline References & Country & NP & Area & Proximity & Pollinator & Matrix & Key results \\
\hline [53] & USA & 8 & $3-215$ & $16-324$ & Honeybee; bumblebee & Farm & $\begin{array}{l}\text { Pollination did not have a significant rela- } \\
\text { tionship with distance from the forest }\end{array}$ \\
\hline [62] & USA & - & - & 1000 & Native and honeybee & Watermelon & $\begin{array}{l}\text { Pollen deposition by native bees was } \\
\text { significantly lower at far farms (those sur- } \\
\text { rounded by }<1 \% \text { natural habitat) }\end{array}$ \\
\hline [58] & Indonesia & - & - & $0-900$ & Native bees & Coffee & $\begin{array}{l}\text { By increasing distance from the forest edge, } \\
\text { social bee abundance decreased. In con- } \\
\text { trast, social bees' densities increased }\end{array}$ \\
\hline [93] & Costa Rica & 3 & $46-111$ & $50-1600$ & Native and honeybee & Coffee & $\begin{array}{l}\text { Visitation rate, pollen deposition, and bee } \\
\text { richness were higher near }(100 \mathrm{~m}) \text { forest } \\
\text { fragments }\end{array}$ \\
\hline [31] & Brazil & - & - & 1000 & Native bees & Coffee & $\begin{array}{l}\text { An increase }(14.6 \%) \text { was observed in farms } \\
\text { near the forest }\end{array}$ \\
\hline [95] & Costa Rica & 2 & $60-100$ & $50-1600$ & Native and honeybee & Coffee & $\begin{array}{l}\text { Bee richness, visiting rate, and pollen } \\
\text { deposition decreased significantly with } \\
\text { increasing distance from forest patches }\end{array}$ \\
\hline [95] & New Zealand & - & - & $0-111$ & Native and honeybee & Kiwifruit & $\begin{array}{l}\text { Visitation of all non-honeybee visitors per } \\
\text { flower was significantly higher for orchards } \\
\text { near native vegetation }\end{array}$ \\
\hline [95] & USA & - & - & 100 & Native bees & Almond & $\begin{array}{l}\text { Despite the proximity of orchards to natural } \\
\text { habitats, there was no substantial visitation } \\
\text { by native species }\end{array}$ \\
\hline [121] & Ecuador & - & - & $100-500$ & Cavity-nesting bees & Rice and coffee & $\begin{array}{l}\text { Forest distance correlated positively with } \\
\text { bee species richness }\end{array}$ \\
\hline [25] & Argentina & - & - & $0-1000$ & Native and honeybee & Grapefruit & $\begin{array}{l}\text { By increasing the distance from the forest, } \\
\text { visiting frequency decreased. At distances } \\
\text { greater than } 500 \mathrm{~m} \text { from forest fragments, } \\
\text { honeybees decreased significantly }\end{array}$ \\
\hline [59] & Indonesia & - & - & $0-1415$ & Megachilidae & Arable land & $\begin{array}{l}\text { By increasing the distance from the forest, } \\
\text { the total number of bees decreased }\end{array}$ \\
\hline [56] & USA & - & - & 2000 & Ground-nesting bees & Sunflower & $\begin{array}{l}\text { More abundant and diverse communi- } \\
\text { ties of bees were found nesting at farms } \\
\text { with patches of natural habitat nearby } \\
\text { than farms that were far away from natural } \\
\text { habitat (having }<25 \% \text { of forest cover in a } \\
\text { radius of } 2 \mathrm{~km} \text { ) }\end{array}$ \\
\hline [126] & USA & - & - & $500-1500$ & Osmia lignaria & Farm & $\begin{array}{l}\text { By increasing distance from forest offspring } \\
\text { reduction increased }\end{array}$ \\
\hline [19] & Costa Rica & 1 & 230 & $0-1500$ & Native and honeybee & Farm and pasture & $\begin{array}{l}\text { Near the forest, honeybees accounted for } \\
5 \% \text { of the total samples, while stingless } \\
\text { bees accounted for } 50 \% \text {. As the distance } \\
\text { from the forest increased, meliponines } \\
\text { decreased to } 20 \% \text { and honeybees } \\
\text { increased to } 45 \%\end{array}$ \\
\hline [100] & Kenya & - & - & $0-5000$ & Honeybees & - & $\begin{array}{l}\text { At distances of less than } 1 \mathrm{~km} \text { from the } \\
\text { forest, the amount of honey produced } \\
\text { was doubled that of the hives located at a } \\
\text { distance of } 3 \mathrm{~km}\end{array}$ \\
\hline [63] & India & - & $0.3-200$ & $10-500$ & Native and honeybee & Coffee & $\begin{array}{l}\text { Distance from forest patches did not affect } \\
\text { pollinators }\end{array}$ \\
\hline [16] & Mexico & 1 & 15 & $1-400$ & Euglossine & Coffee & $\begin{array}{l}\text { By increasing the distance from the forest, } \\
\text { euglossine abundance decreased }\end{array}$ \\
\hline [12] & India & - & - & 1400 & Social bee & Coffee & $\begin{array}{l}\text { By increasing the distance from the forest, } \\
\text { the total visitor abundance decreased in } \\
\text { rain-fed agroforests }\end{array}$ \\
\hline [77] & Argentina & - & - & $5-1000$ & Honeybee & Soybean & $\begin{array}{l}\text { By increasing the distance from the forest, } \\
\text { total visitation rates decreased }\end{array}$ \\
\hline
\end{tabular}


Table 1 (continued)

\begin{tabular}{|c|c|c|c|c|c|c|c|}
\hline References & Country & NP & Area & Proximity & Pollinator & Matrix & Key results \\
\hline [2] & Brazil & 2 & $900-1200$ & $100-1000$ & Euglossine & Pasture & $\begin{array}{l}\text { By increasing distance from forest, abun- } \\
\text { dance, richness, and diversity of orchid bees } \\
\text { decreased }\end{array}$ \\
\hline [14] & Spain & 1 & 40 & $500-1800$ & Honeybee; native bees & Farm & $\begin{array}{l}\text { Honeybee abundance can increase with } \\
\text { greater distance from the forest }\end{array}$ \\
\hline [109] & Thailand & 10 & $3.6-650$ & 20,000 & Stingless bees & Orchard & $\begin{array}{l}\text { Pollination success in near farms }(<1 \mathrm{~km}) \\
\text { was enhanced substantially by proximity to } \\
\text { the forest than far farms }(>7 \mathrm{~km})\end{array}$ \\
\hline [52] & USA & - & - & $0-1000$ & Native and honeybee & Orchard & $\begin{array}{l}\text { By increasing the distance from forest } \\
\text { patches, the number of bee visits to apple } \\
\text { flowers decreased }\end{array}$ \\
\hline [30] & Brazil & 1 & 2176 & $250-500$ & Cavity-nesting bees & Farm & $\begin{array}{l}\text { At the forest edge, parasitism and mortality } \\
\text { were more observed }\end{array}$ \\
\hline [49] & Brazil & - & - & 1500 & Apoidea & Coffee & $\begin{array}{l}\text { Reducing yield gaps and higher biodiversity } \\
\text { were found in farms near the forest }\end{array}$ \\
\hline [105] & Brazil & 1 & 0.6 & $600-4000$ & Xylocopa & Passion fruit & $\begin{array}{l}\text { By increasing the distance from the forest, } \\
\text { total visitation rates of Xylocopa decreased }\end{array}$ \\
\hline [108] & Thailand & 10 & $360-65,000$ & $50-30,000$ & Stingless bee & Orchard & $\begin{array}{l}\text { At sites near }(<1 \mathrm{~km}) \text { the forest, the average } \\
\text { number of visitor interactions was higher }\end{array}$ \\
\hline [22] & Indonesia & - & - & $200-1000$ & Native bees & Cucumber & $\begin{array}{l}\text { In farms near }(<200) \text { to the forest, pollina- } \\
\text { tors were significantly lower compared to } \\
\text { farms far }(>1000) \text { from the forest } \\
\text { Distance from the forest did not affect the } \\
\text { productivity of cucumbers }\end{array}$ \\
\hline [71] & Brazil & - & - & $500-1500$ & Stingless bee & Mixed & $\begin{array}{l}\text { By increasing distance from forest, Stingless } \\
\text { bee richness decreased regardless of body } \\
\text { size. In contrast, stingless bee body size } \\
\text { increased }\end{array}$ \\
\hline [86] & Brazil & 14 & $1-39$ & 500 & Native bees & Pasture & $\begin{array}{l}\text { By increasing the distance from the forest, } \\
\beta \text {-diversity increased }\end{array}$ \\
\hline [107] & Estonia & - & - & 2000 & Bumblebee & Farm & $\begin{array}{l}\text { The species richness and abundance were } \\
\text { higher in the margins next to the forest } \\
\text { compared to the margins next to open } \\
\text { habitats }\end{array}$ \\
\hline [32] & Nepal & - & - & $100-2100$ & Honeybee; solitary bees & Mustard & $\begin{array}{l}\text { By increasing the distance from the forest, } \\
\text { diversity measures decreased }\end{array}$ \\
\hline [46] & Brazil & - & - & 400 & Meliponini & Coffee & $\begin{array}{l}\text { By increasing distance from forest, bee } \\
\text { richness and abundance decreased. Bee } \\
\text { abundance decreased only when the cof- } \\
\text { fee cover dominated the landscapes matrix }\end{array}$ \\
\hline [50] & Argentina & - & $1-15$ & $0-200$ & Native and honeybees & Soybean & $\begin{array}{l}\text { By increasing distance from forest, pollen } \\
\text { deposition and total visitation rates of } \\
\text { native bees decreased }\end{array}$ \\
\hline [99] & Mexico & - & - & 1000 & Native bees & Soybean & $\begin{array}{l}\text { The presence of preserved patches contrib- } \\
\text { utes to the richness and the abundance of } \\
\text { bees, due to the maintenance of wildflow- } \\
\text { ers and ruderal plants in patches next to } \\
\text { the crop fields, providing a continuous } \\
\text { source of pollen }\end{array}$ \\
\hline [125] & Thailand & - & - & $1500-15,000$ & Stingless bees & Orchard & $\begin{array}{l}\text { By increasing the distance from the forest, } \\
\text { pollinator specialization decreased }\end{array}$ \\
\hline
\end{tabular}

radius around the sampling sites to be $2 \mathrm{~km}$. Social pollinators such as honeybees, bumblebees, and stingless bees are studied in $53 \%$ of the studies.

Approximately, $67 \%$ of the studies have reported that regardless of the species under study, the radius, and the matrix around the sampling sites, the presence of forest cover around the sites has positive effects on the bee richness, abundance, and visiting rate. For example, Ferreira et al. [38] claim that forest cover is the most important factor to increase bee abundance and richness. However, 
Table 2 Country, buffer $(m)$, type of pollinators, matrix around the sampling sites, and key results of studies that have examined the effects of the amount of forest cover in a landscape on bees

\begin{tabular}{|c|c|c|c|c|c|}
\hline References & Country & Buffer & Pollinator & Matrix & Key results \\
\hline [42] & Spain & $10-100$ & Honeybees & Pasture & $\begin{array}{l}\text { By decreasing forest cover, fruit set and the number } \\
\text { of developing pollen tubes per flower decreased }\end{array}$ \\
\hline [117] & Canada & 250-1500 & Native bees & Corn and soybean & $\begin{array}{l}\text { Only at the buffer of } 750 \mathrm{~m} \text { from the forest, bee } \\
\text { abundance and richness were positively correlated } \\
\text { with the forest cove }\end{array}$ \\
\hline [19] & Costa Rica & $0-1500$ & Native and honeybee & Farm and pasture & $\begin{array}{l}\text { By increasing forest cover proportion at scales from } \\
200 \text { to } 1200 \mathrm{~m} \text {, Meliponine richness increased }\end{array}$ \\
\hline [128] & USA & $500-3000$ & Native bees & Farm & $\begin{array}{l}\text { Forest cover did not affect crop visitation by wild } \\
\text { bees }\end{array}$ \\
\hline [20] & Costa Rica & 200 & Native and honeybee & Farm and pasture & $\begin{array}{l}\text { By increasing forest cover proportion, tree-nesting } \\
\text { Meliponines increased while honeybees showed } \\
\text { opposite patterns }\end{array}$ \\
\hline [17] & Costa Rica & 400 & Stingless bees & Farm & $\begin{array}{l}\text { Forest cover proportion positively affected } \\
\text { Meliponine richness and abundance }\end{array}$ \\
\hline [119] & Japan & $500-4000$ & Apis cerana & Farm & $\begin{array}{l}\text { Forest cover proportion within the } 1500-\mathrm{m} \text { buffer } \\
\text { positively affected } A \text {. cerana abundance in the farms }\end{array}$ \\
\hline [15] & Germany & $250-2000$ & Native and honeybee & Wild cherry & Forest cover proportion did not affect bees \\
\hline [115] & Canada & $120-2020$ & Native and honeybee & Farm & $\begin{array}{l}\text { Forest cover proportion negatively affected the total } \\
\text { number of species and the number of interaction } \\
\text { links between plant and pollinator at buffers of } 1520 \\
\text { and } 1620 \mathrm{~m} \text {, respectively }\end{array}$ \\
\hline [51] & USA & $250-1000$ & Bumblebee & Mixed & $\begin{array}{l}\text { Native species richness was significantly lower in } \\
\text { landscapes with greater riparian forest cover }\end{array}$ \\
\hline [97] & Mexico & 1700 & Frieseomelitta nigra; Apis mellifera & Plantation & $\begin{array}{l}\text { Forest cover proportion positively affected bee } \\
\text { diversity and abundance on plantations }\end{array}$ \\
\hline [129] & Canada & 400 & Native bees & Grassland & Forest cover proportion did not affect bees \\
\hline [103] & Brazil & $250-2000$ & Euglossine & Soya, and maize & Forest cover proportion did not affect bees \\
\hline [101] & Brazil & $300-2000$ & Native bees and honeybee & Coffee & $\begin{array}{l}\text { Forest cover proportion positively affected native } \\
\text { bee abundance, richness, and diversity at all buffers } \\
\text { Forest cover proportion at the } 300 \mathrm{~m} \text { scale nega- } \\
\text { tively affected honeybee abundance }\end{array}$ \\
\hline [26] & Switzerland & 500 & Osmia bicornis & Farm & $\begin{array}{l}\text { Forest cover proportion did not affect the abun- } \\
\text { dance of O. bicornis }\end{array}$ \\
\hline [113] & Brazil & $250-2000$ & Euglossine & Water & $\begin{array}{l}\text { Forest cover proportion positively affected bee rich- } \\
\text { ness within a buffer of } 250 \mathrm{~m}\end{array}$ \\
\hline [39] & Brazil & $750-3000$ & Native bees & Tomato & $\begin{array}{l}\text { Forest cover proportion positively affected the abun- } \\
\text { dance of all pollinator groups }\end{array}$ \\
\hline [64] & Mexico & $200-1000$ & Native bees & Farm & $\begin{array}{l}\text { Forest cover proportion positively affected bee rich- } \\
\text { ness, particularly species of the family Apidae }\end{array}$ \\
\hline [102] & Brazil & $250-2000$ & Solitary and honeybee & Soya, and maize & $\begin{array}{l}\text { Forest cover proportion negatively affected the } \\
\text { abundance of solitary bees at both } 1000 \text { and } 1250 \mathrm{~m} \\
\text { scales }\end{array}$ \\
\hline [24] & Brazil & $500-1000$ & Trigona spp. & Farm & $\begin{array}{l}\text { Forest cover proportion positively affected bee } \\
\text { visitation rate }\end{array}$ \\
\hline [85] & India & $100-2000$ & Honeybee & Coffee & $\begin{array}{l}\text { Positive effects of agroforests, forest fragments, } \\
\text { and land cover heterogeneity on the presence and } \\
\text { number of nests }\end{array}$ \\
\hline [124] & Mexico & $250-2000$ & Native bees & Soybean and maize & $\begin{array}{l}\text { Polycultures farms that had the greatest proportion } \\
\text { of surrounding forest cover showed the highest bee } \\
\text { richness }\end{array}$ \\
\hline [71] & Brazil & $500-1500$ & Stingless bees & Mixed & $\begin{array}{l}\text { Forest cover proportion negatively affected stingless } \\
\text { bee body size; mean community body size was } \\
\text { larger in areas with greater amounts of deforesta- } \\
\text { tion, and smaller in areas with less deforestation }\end{array}$ \\
\hline [72] & USA & $500-5000$ & Native bees & Cornfields & $\begin{array}{l}\text { Forest cover proportion negatively affected bee } \\
\text { abundance but positively affected bee richness }\end{array}$ \\
\hline
\end{tabular}


Table 2 (continued)

\begin{tabular}{|c|c|c|c|c|c|}
\hline References & Country & Buffer & Pollinator & Matrix & Key results \\
\hline [38] & Brazil & 25 & Native bees & Deforested areas & $\begin{array}{l}\text { Forest cover was the most important factor to } \\
\text { increase bee abundance and richness }\end{array}$ \\
\hline [35] & Guatemala & $300-2000$ & Bumble and stingless bees & Corn, green bean & $\begin{array}{l}\text { By increasing forest cover proportion, bumblebee } \\
\text { abundance increased }\end{array}$ \\
\hline [27] & Costa Rica & 200 & Euglossine & - & $\begin{array}{l}\text { Forest cover proportion positively affected orchid } \\
\text { bee visitation }\end{array}$ \\
\hline [125] & Thailand & $1500-15,000$ & Stingless bees & Mixed fruit orchards & $\begin{array}{l}\text { Forest cover proportion positively affected stingless } \\
\text { bee richness and abundance }(<2 \mathrm{~km})\end{array}$ \\
\hline [7] & France & $500-3000$ & Native and honeybees & Orchard & $\begin{array}{l}\text { Forest cover at } 500 \mathrm{~m} \text { increased most of all wild } \\
\text { hymenopteran abundance and, while forest cover at } \\
3 \mathrm{~km} \text { promoted average abundance including the } \\
\text { domestic honeybee }\end{array}$ \\
\hline [33] & USA & $250-1000$ & Native bees & Lowbush blueberry & $\begin{array}{l}\text { Bee abundance and richness decreased in cover } \\
\text { types with few floral resources such as coniferous } \\
\text { and deciduous/mixed forest }\end{array}$ \\
\hline [111] & Germany & $250-3000$ & Native and honeybee & Mixed & $\begin{array}{l}\text { At } 750 \mathrm{~m} \text { scale, forest cover proportion positively } \\
\text { affected bee richness and abundance of solitary } \\
\text { bees whereas bumblebees and honeybees did not } \\
\text { respond to landscape context at these scales } \\
\text { Forest cover proportion negatively affected honey- } \\
\text { bees at a radius of } 3000 \mathrm{~m}\end{array}$ \\
\hline [96] & Brazil & $400-1000$ & Native bees & Forest & $\begin{array}{l}\text { Forest cover proportion negatively affected the } \\
\text { functional richness of reproductive plant attributes }\end{array}$ \\
\hline [107] & Estonia & 2000 & Bumblebee & Farm & $\begin{array}{l}\text { Forest cover proportion increased bumblebee rich- } \\
\text { ness and abundance }\end{array}$ \\
\hline
\end{tabular}

$15 \%$ of the studies reported the negative effects of forest cover on bee populations. For example, Miljanic et al. [72] found that the percent of forest cover had negative relationships with bee abundance, but positively affected bee richness. Saturni et al. [101] also found forest cover positively affected bee diversity, richness, and abundance. However, at the $300 \mathrm{~m}$ scale, forest cover negatively affected honeybee abundance. Eighteen percent of the studies also found no link between bees and forest cover.

\section{Structural effects of forest fragments on bees}

Table 3 details the studies that examined the effects of size, isolation, shape, fragmentation of forest patches on bees. Tables 1, 2 provided details of studies that examined the effect of forest patches on the surrounding landscape, i.e., agricultural farms, while Table 3 provides studies that examined the population of bees within forest patches, not the surrounding landscape. This table presents 31 articles, $29 \%$ of which have been done in Brazil, which has the highest proportion compared to other countries. The number of forest patches studied in these studies varies from 2 to 30 with an average of 11 patches. The area of these patches varies from 0.01 to 1 million hectares. Most of the pollinators studied in these articles are from the euglossine tribe (28\%). The isolation column shows the distance between forest fragments in kilometers, which varies from 0.05 to $500 \mathrm{~km}$.
Twenty-three articles have examined the effects of forest patch size on the bee's population within the patches. Some of these studies have found that larger patches support a larger population of bees, in other words, with decreasing the size of forest patches, bee abundance and richness decreases or $[3,5,18,20,23,45,47,48,82$, $106,114]$. However, some studies have shown that small patches support more species abundance and richness than large patches $[1,47,68,122]$. Some studies have also found that the size of forest patches does not affect bee populations $[36,65,79,98,110]$, and others claim that the capacity of small patches to support pollinators is the same as that of large ones $[78,118,130]$. The shape of forest patches also affects the presence of bees. For example, Knoll and Penatti [61] showed that there is a high negative correlation between the bee abundance and the forest shape index. Lázaro et al. [66] also found that patch complexity negatively affected the overall number of pollinator visits.

Table 4 summarizes the results of Tables $1,2,3$. This table briefly shows that most studies related to the effect of forest patches on bee diversity have been conducted in Brazil. In addition, more than $79 \%$ of studies have considered distances less than $2 \mathrm{~km}$ to examine the amount, distance-dependent, and structural effects of forest cover on bees. Most of the forest patches also had a size of more than 100 hectares. More than $63.8 \%$ of the studied 
Table 3 Country, number (NP) and area (ha) of forest patches, type of pollinators, matrix around forest patches, isolation (km), and key results of studies that have investigated the structural effects of forest patches on bees

\begin{tabular}{|c|c|c|c|c|c|c|c|}
\hline References & Country & NP & Area & Pollinator & Matrix & Isolation & Key results \\
\hline [4] & Argentina & 8 & $0.5-480$ & Native and honeybee & Cornfield & - & $\begin{array}{l}\text { By decreasing patch size, the } \\
\text { frequency and richness of } \\
\text { native bees declined but the } \\
\text { relative numbers of honeybees } \\
\text { increased. Honeybees visiting } \\
\text { were negatively correlated with } \\
\text { individual trees }\end{array}$ \\
\hline [120] & Brazil & 2 & 50 & Euglossine & - & - & $\begin{array}{l}\text { Euglossine bees moved over } \\
\text { cleared areas in search of } \\
\text { fragrances }\end{array}$ \\
\hline [78] & Panama & 10 & $1-1500$ & Euglossine & Mixed & $100-500$ & $\begin{array}{l}\text { Euglossine bees recorded } \\
\text { on islands were visitors from } \\
\text { mainland sites and were equally } \\
\text { frequent in fragments and con- } \\
\text { tinuous forest }\end{array}$ \\
\hline [68] & Brazil & 8 & $1-50,000$ & Bombus brasiliensis & Farm & 4 & $\begin{array}{l}\text { Patches maintain greater rich- } \\
\text { ness and frequency of floral } \\
\text { visitors than continuous sites }\end{array}$ \\
\hline [20] & Costa Rica & 22 & $0.25-230$ & Native and honeybee & Farm; pasture & 500 & $\begin{array}{l}\text { Tree-nesting Meliponines were } \\
\text { correlated with larger patches, } \\
\text { smaller edge: area ratios. Honey- } \\
\text { bees showed opposite patterns }\end{array}$ \\
\hline [122] & Chile & 5 & $2-600$ & Native bees & Pine plantation & - & $\begin{array}{l}\text { Small patches had higher species } \\
\text { richness than continuous forests }\end{array}$ \\
\hline [18] & Costa Rica & 22 & $0.25-230$ & Euglossine & Pasture & $0.5-19$ & $\begin{array}{l}\text { Euglossine bees' abundance was } \\
\text { significantly positively correlated } \\
\text { to forest patch size, negatively } \\
\text { related to forest shape. Richness } \\
\text { was negatively related to frag- } \\
\text { ment area, and not related to } \\
\text { fragment isolation }\end{array}$ \\
\hline [47] & Spain & 6 & $2-140$ & Native and honeybee & Farm & $1-20$ & $\begin{array}{l}\text { Large patches supported a } \\
\text { greater flower visitor diversity, } \\
\text { but small patches tended to } \\
\text { have higher insect visitation rates }\end{array}$ \\
\hline [79] & Brazil & 9 & $1-354$ & Euglossine & Farm & $>100$ & $\begin{array}{l}\text { Fragment size or ratio area/ } \\
\text { perimeter did not affect the } \\
\text { abundance and richness of } \\
\text { euglossine bees but the size of } \\
\text { core areas positively affected } \\
\text { them }\end{array}$ \\
\hline [131] & Switzerland & - & - & $\begin{array}{l}\text { Chelostoma florisomne; Hoplitis } \\
\text { adunca }\end{array}$ & Farm & - & $\begin{array}{l}\text { Forests covering a distance of } \\
\text { up to } 480 \mathrm{~m} \text { were crossed by } \\
\text { Chelostoma florisomne }\end{array}$ \\
\hline [23] & Mexico & 14 & $0.07-24.9$ & Native bees & Pasture & 2 & $\begin{array}{l}\text { Patch size positively affected bee } \\
\text { richness and diversity }\end{array}$ \\
\hline [130] & Mexico & - & - & Euglossa dilemma & Farm & $130-200$ & $\begin{array}{l}\text { Bee populations forest remnants } \\
\text { were neither differentiated from } \\
\text { nor had less genetic diversity } \\
\text { than, populations in near-con- } \\
\text { tinuous forest separated from } \\
130 \mathrm{~km} \text { of agricultural lands }\end{array}$ \\
\hline [1] & Brazil & 9 & $2-18$ & Euglossine & Pasture; tomato & $0.05-135$ & $\begin{array}{l}\text { The smallest forest patch had the } \\
\text { highest abundance of bees }\end{array}$ \\
\hline [61] & Brazil & 4 & $287-94,000$ & Euglossine & Coffee & - & $\begin{array}{l}\text { Forest shape index negatively } \\
\text { affected euglossine abundance }\end{array}$ \\
\hline [5] & Brazil & 3 & $100-280$ & Euglossine & Pasture & 3 & $\begin{array}{l}\text { The largest fragment was the } \\
\text { main source of the observed } \\
\text { variation in species richness and } \\
\text { abundance }\end{array}$ \\
\hline
\end{tabular}


Table 3 (continued)

\begin{tabular}{|c|c|c|c|c|c|c|c|}
\hline References & Country & NP & Area & Pollinator & Matrix & Isolation & Key results \\
\hline [82] & Tanzania & 6 & - & Megachile & Tea & - & $\begin{array}{l}\text { Continuous fragments had a } \\
\text { higher diversity of pollinators } \\
\text { than forest patches }\end{array}$ \\
\hline [48] & Australia & 4 & $0.15-30$ & Honeybee & Farm & - & $\begin{array}{l}\text { Honeybee abundance and } \\
\text { pollen deposition were lower in } \\
\text { small patches }\end{array}$ \\
\hline [36] & New Zealand & 15 & $0.01-1,000,000$ & Bumblebee & Grassland & - & $\begin{array}{l}\text { Patch area did not affect } \\
\text { variation in the abundance or } \\
\text { biomass of bumblebees }\end{array}$ \\
\hline [45] & Brazil & 5 & $3-484$ & Native bees & Soybean & 20 & $\begin{array}{l}\text { Patch size positively affected } \\
\text { the abundance of Apinae and } \\
\text { oligolectic bees and nega- } \\
\text { tively affected the richness of } \\
\text { Augochlorini bees }\end{array}$ \\
\hline [114] & Canada & 3 & $7-350$ & Andrena & Forest & - & $\begin{array}{l}\text { Two small fragments had higher } \\
\text { reductions in reproductive out- } \\
\text { put than the continuous ( } 350 \text { ha) } \\
\text { fragment }\end{array}$ \\
\hline [10] & Ethiopia & - & $4-100,000$ & Honeybee & Coffee & - & $\begin{array}{l}\text { Forest fragmentation increased } \\
\text { the relative abundance of } \\
\text { honeybees }\end{array}$ \\
\hline [98] & Brazil & - & - & $\begin{array}{l}\text { Eulaema } \\
\text { Athletica }\end{array}$ & Oil palm; rubber tree & & $\begin{array}{l}\text { Fragment size and isolation did } \\
\text { not affect genetic diversity }\end{array}$ \\
\hline [110] & Costa Rica & 12 & $0.9-16$ & Native bees & Farm & 2 & $\begin{array}{l}\text { Fragment size did not affect } \\
\text { bee abundance, diversity, and } \\
\text { parasitism, and mortality rates in } \\
\text { trap nests. Total bee abundance } \\
\text { did not vary from edge to center. } \\
\text { Species diversity was higher in } \\
\text { the forest center }\end{array}$ \\
\hline [13] & Ecuador & 19 & $2.5-3500$ & Euglossine & Farm & $0.3-17$ & $\begin{array}{l}\text { Fragments area and isolation did } \\
\text { not affect bee abundance, rich- } \\
\text { ness, or evenness }\end{array}$ \\
\hline [80] & Brazil & 30 & $15-25$ & Native bees & Mixed & - & $\begin{array}{l}\text { Open areas had higher bee } \\
\text { richness and diversity than forest } \\
\text { patches }\end{array}$ \\
\hline [106] & Australia & 14 & $>5,<20$ & Native bees & - & - & $\begin{array}{l}\text { Large forest fragments had } \\
\text { higher taxonomic diversity of } \\
\text { bees visiting flowers of trees } \\
\text { than small fragments. Small } \\
\text { fragments had higher mean } \\
\text { body sizes than those in larger } \\
\text { fragments. The abundance of } \\
\text { stingless bees decreased in small } \\
\text { fragments compared to large } \\
\text { fragments }\end{array}$ \\
\hline [118] & Japan & 13 & $1.3-10$ & Native bees & Farm & - & $\begin{array}{l}\text { Small patches can have the same } \\
\text { potential in maintaining as large } \\
\text { patches. Bee richness quickly } \\
\text { increased at the small range of } \\
\text { the area ( }<3 \text { ha) }\end{array}$ \\
\hline [65] & USA & 14 & $5-164$ & Solitary bees & Mixed & $0.6-19$ & $\begin{array}{l}\text { Forest patch size did not affect } \\
\text { bee community structure or } \\
\text { individual family occupancy }\end{array}$ \\
\hline [76] & USA & - & - & $\begin{array}{l}\text { Bombus vosnesenskii; Bombus } \\
\text { bifarius }\end{array}$ & Forest & - & $\begin{array}{l}\text { Forests did not act as barriers } \\
\text { to the fine-scale movement for } \\
\text { either species }\end{array}$ \\
\hline
\end{tabular}


Table 3 (continued)

\begin{tabular}{|c|c|c|c|c|c|c|c|}
\hline References & Country & NP & Area & Pollinator & Matrix & Isolation & Key results \\
\hline [44] & Norway & 24 & $0.11-72$ & Bumblebee & Farm & $0-428$ & $\begin{array}{l}\text { Patch isolation negatively } \\
\text { affected bumblebee abundance } \\
\text { Forest fragmentation reduced } \\
\text { the abundance of forest special- } \\
\text { ists while increasing the abun- } \\
\text { dance of open-habitat species }\end{array}$ \\
\hline [66] & Norway & 24 & - & Native bees & Farm & - & $\begin{array}{l}\text { Patch complexity negatively } \\
\text { affected the total number of } \\
\text { pollinators }\end{array}$ \\
\hline
\end{tabular}

Table 4 Summary of the results of studies investigating amount, distance-dependent, and structural effects of forest patches on bees

\begin{tabular}{llllll}
\hline & Country (\%) & Distance/area (\%) & Species (\%) & Matrix (\%) & Results (\%) \\
\hline Distance-dependent effects $(n=36)$ & Brazil (22) & $<2 \mathrm{~km}(83.3)$ & Native bee (63.8) & Coffee (27.7) & Negative (77.7) \\
& Other (78) & $>2 \mathrm{~km}(16.7)$ & Honeybee (36.1) & Other (72.3) & Positive (13.5) \\
Amount effects $(n=33)$ & Brazil (27.7) & $<2 \mathrm{~km}(75.7)$ & Native bee (85) & Soybean (12) & Negative (21) \\
& Other (72.3) & $2 \mathrm{~km}(29.3)$ & Honeybee (15) & Other (88) & Positive (66.6) \\
Structural effects $(n=31)$ & Brazil (29) & Area $<100$ ha (36) & Native bee (84) & Farm (58) & Negative (17) \\
& Other (71) & Area $>100$ ha (64) & Honeybee (16) & Other (42) & Positive (47) \\
\hline
\end{tabular}

species were native bees and less attention was paid to honey bees in these studies. Both coffee and soybean crops have received more attention than other products. In the results column, the effects of amount, distancedependent, and structural effects of forest patches on bee diversity are presented. For the distance-dependent effects of forest patches, negative means that the diversity of bees decreases with increasing distance from the forest. For the effects of the amount of forest cover, positive means that the presence of more forest cover has increased the diversity of bees. For the structural effects of patches, positive means that larger patches support a higher diversity of bees.

\section{Discussion}

Our data on the distance-dependent effects of forest patches showed that the bees' population and consequently pollination decreases with increasing distance from forest patches in agricultural farms. This result was confirmed by $77 \%$ of the studies presented in Table 1 . However, $13.5 \%$ of these studies disagreed with this result, and $9 \%$ of the studies found no relationship between distance from forest patches and bees. The first question that arises in this regard is: at what distance from the forest patches a significant reduction of bees occurs? Various studies have examined different distances ranging from zero to $30 \mathrm{~km}$ of forest patches with an average of $1900 \mathrm{~m}$. Although these studies do not specify at what distance from forest patches, for example, the bee population decreases by $50 \%$, some studies claim that this decrease is exponential $[55,69$, $75,94]$. For example, in a review study, Ricketts et al. [94] showed that with increasing distance from forest patches, the visiting rate and the abundance of pollinators decreased exponentially.

Nearly, $79 \%$ of our studies that have found a significant decrease in bees by increasing distances from forest patches have examined distances of less than $2 \mathrm{~km}$. Therefore, it seems that at distances of more than $2 \mathrm{~km}$ from the forest patches we should not expect a significant presence of bees. For large-bodied bees, such as honeybees that can fly several kilometers, Chacoff and Aizen [25] found that honeybees decreased at distances greater than $500 \mathrm{~m}$ from the forest edge. Buchori et al. [22] also showed that pollinators were significantly lower on farms near $(<200)$ to natural habitats compared to those located far $(>1000)$. Another question is whether the size of forest patches affects the decreasing rate of bees with increasing distance from the patches. In other words, is there a difference between the distance-dependent effects of large and small patches? We mentioned earlier that the area of forest patches in the studies varies from 0.3 hectares to 65,000 hectares, with an average of 3100 hectares. None of these studies reported that with a distance of large patches, for example, 65,000 hectares [108], the rate of bee reduction is different from small patches. Therefore, it seems that even in the case of large patches, the population 
of bees at distances of more than $2 \mathrm{~km}$ significantly decreases.

One possible reason is that bees are unable to fly long distances. In a review, Zurbuchen et al. [132] examined the maximum foraging distances of bees. They found that the average maximum foraging distance for solitary bees was 1220 , bumblebees 14,670 , stingless bees 1520 , and honeybees were about $6313 \mathrm{~m}$. Therefore, as mentioned earlier, regardless of the size of forest patches, the type of species, and the matrix around the patches, the bees' population decreases significantly at distances more than $2 \mathrm{~km}$. Another reason is that bees are the central place forger. Many animals, including bees, return to a central location after collecting food. Factors such as time, energy, and risk associated with the predator when transporting food to the nest also affect the location of the nests [84]. Central foragers build their nest in a place so that they save maximum energy and apply minimal effort to find the required resources. According to this theory, there is a maximum distance for the central place foragers that they do not go beyond this distance for foraging. Therefore, near the nest patches, all high-quality patches are visited, but at distances away from the nests, only the best patches are used [83].

Our data on the effects of forest cover on bees in agricultural landscapes showed that the presence of forest cover around the sampling sites has a positive effect on the presence of bees. This result was confirmed by $67 \%$ of the studies presented in Table 2. In these studies, the buffer around the sampling sites varied from $25 \mathrm{~m}$ to $15 \mathrm{~km}$ with an average of $1350 \mathrm{~m}$. In other words, they measured the amount of forest cover in circles with an area of 0.19-70,650 hectares with an average of 572 hectares and examined its effects on bee populations. The question that arises here is in which radius of the sampling sites the highest correlation is seen between forest cover and bee population. Approximately, $76 \%$ of the studies that found the presence of forest cover positively affects the presence of bees; the maximum radius was less than $2 \mathrm{~km}$. Therefore, it seems that by creating new forest cover in a radius of $2 \mathrm{~km}$ around the target sites, we can significantly increase the bee population. Wayo et al. [125] also showed that forest cover has a strong positive effect on stingless bee richness and abundance in a radius less than $2 \mathrm{~km}$.

Some studies have provided the most important radius in their results. For example, Taki et al. [117] identified that only at the buffer of $750 \mathrm{~m}$, forest cover had a positive effect on the and bee abundance and richness. At buffers from 200 to 1200 , Brosi et al. [19] found that forest covers positively affected Meliponine richness. At the 1500-m scale, Taki et al. [119] also found a positive effect of forest cover on the abundance of $A$. cerana.
Storck-Tonon and Peres [113] identified a radius of $250 \mathrm{~m}$ for positive effects of forest cover on bee richness. RochaSantos et al. [96] found that reproductive attributes of trees vanished quickly from forest remnants at a threshold at $25-30 \%$ of forest cover in the landscape. The sociality and generality of the bees can also affect the response that they give to the surrounding landscape. For example, Silva et al. [102] found that social bees responded to landscape characteristics at narrow scales $(250 \mathrm{~m})$, and solitary bees responded to broader scales $(2000 \mathrm{~m})$. Ferreira et al. [38] also found that specialist bees were more abundant in landscapes with more than $30 \%$ forest cover. With declining habitat, generalist species will appear more due to a lack of food resources. In landscapes where forest cover is less than $15 \%$, pollinator populations may become extinct locally in small patches [38].

Our data also show that larger forest patches maintain a larger population of bees than smaller ones. Of the 23 articles that surveyed bee populations in forest patches, 11 (47\%) found that larger patches had a greater potential than small ones to maintain a bee population. Some studies have shown the opposite (17\%) and three articles claimed that the capacity of large and small patches was equal in maintaining bees, and $23 \%$ of studies found no significant relationship between patches size and bees. The area of forest patches in studies claiming that larger patches have a higher diversity and abundance of bees varies from 0.07 to 484 hectares, with an average of 125 hectares. These studies did not specify how much habitat was sufficient to maintain a viable population of bees and only compared patches that differed in size. For example, in a comparison between 14 patches having an area between 0.07 and 24 hectares, Calvillo et al. [23] found that the species diversity and richness in a 24-hectare patch was greater than the smaller ones. However, in a study comparing nine patches with areas between 2 and 18 hectares, Aguiar and Gaglianone [1] found that the smallest forest fragment had the highest abundance of bees. Therefore, no conclusion can be drawn about the size of the new patches needed to increase the bee population.

In addition to the size of the patches, it is necessary to determine the number and fragmentation pattern of new patches in a landscape. For example, Mitchell et al. [75] showed that the maximum levels of pollination occurred at the moderate habitat amounts fragmentation levels. Maurer et al. [70] found that forest fragmentation negatively affected bumblebees at low habitat amounts. At high habitat amounts, they found positive effects. In landscapes with low fragmentation, they also reported increased bee foraging activity. They found that fragmentation effects were strongly dependent on habitat amount in the landscapes. 


\section{Conclusion}

Generally, our data showed that (1) by increasing the distance from forest patches, regardless of the type of species, the type of agricultural product around the patches, the size and number of patches, the bees' diversity and abundance decrease, (2) the presence of forest cover around the agricultural fields in most cases increases the population of bees in the fields, and (3) no conclusion can be drawn about the effects of forest patches size, shape, and number on the bee population. To determine how to increase pollination service in agricultural landscapes by creating new forest patches, two simulation studies have been performed recently. Based on the Lonsdorf model [67], Rahimi et al. [91] showed that maximum crop pollination occurred in the landscapes that had the highest forest fragmentation, meaning that new forest patches should be small and scattered in the landscape. In a similar study, they showed that if the capacity of small forest patches in supplying nests for bees is high, new small patches should be created sparsely around the fields. However, if the capacity of forest patches is low, the suggestion is to create large patches in smaller numbers around the farms [89]. Using artificial nests for attracting bees can also increase the capacity of small forest patches in supplying pollination [90]. In the present study, we sought experimental confirmations for the results of the simulation studies, but none of the studies we examined provided a clear answer to the question of how pollination could be increased by creating new forest patches. Therefore, future experimental studies need to seek answers to the following questions: (1) at what distance from the forest patches the bee population reaches $50 \%$ of its original population? (2) What percentage of the forest cover around farms guarantees an efficient population of bees for increasing pollination? Answering these questions can help landscape managers to estimate the optimal spatial pattern for new forest patches for increasing pollination.

\section{Acknowledgements}

Not applicable.

\section{Authors' contributions}

ER: conceptualizing, reviewing, and writing. SB has reviewed the paper and helped to respond to the paper's questions. PD has reviewed the paper, edited grammar, and helped to respond to the paper's questions. All authors read and approved the final manuscript.

\section{Funding}

There are no Financial conflicts of interest to disclose.

\section{Availability of data and materials}

Data are available on request from the authors only based on logical requests.

Code availability

Not applicable.

\section{Declarations}

Ethics approval and consent to participate

Not applicable.

Consent for publication

Not applicable.

Competing interests

The authors declare that they have no competing interests.

\section{Author details}

${ }^{1}$ Environmental Sciences Research Institute, Shahid Beheshti University, Tehran, Iran. ${ }^{2}$ Department of Geography and the Environment, University of North Texas, Denton, TX, USA.

Received: 28 July 2021 Accepted: 10 January 2022

Published online: 21 January 2022

References

1. Aguiar WMD, Gaglianone MC. Euglossine bee communities in small forest fragments of the Atlantic Forest, Rio de Janeiro state, southeastern Brazil (Hymenoptera, Apidae). Rev Bras Entomol. 2012;56(2):210-9.

2. Aguiar WMD, Sofia SH, Melo GA, Gaglianone MC. Changes in orchid bee communities across forest-agroecosystem boundaries in Brazilian Atlantic Forest landscapes. Environ Entomol. 2015:44(6):1465-71.

3. Aizen MA, Feinsinger P. Forest fragmentation, pollination, and plant reproduction in a Chaco dry forest, Argentina. Ecology. 1994;75(2):330-51.

4. Aizen MA, Feinsinger P. Habitat fragmentation, native insect pollinators, and feral honey bees in Argentine 'Chaco Serrano.'Ecol Appl. 1994:4(2):378-92.

5. Andrade-Silva ACR, Nemésio A, de Oliveira FF, Nascimento FS. Spatialtemporal variation in orchid bee communities (Hymenoptera: Apidae) in remnants of arboreal Caatinga in the Chapada Diamantina region, State of Bahia, Brazil. Neotrop Entomol. 2012;41(4):296-305.

6. Assembly G. Resolution adopted by the General Assembly on $19 \mathrm{Sep}$ tember 2016, A/RES/71/1, 3 October 2016 (The New York Declaration). 2015.

7. Bartholomée O, Aullo A, Becquet J, Vannier C, Lavorel S. Pollinator presence in orchards depends on landscape-scale habitats more than in-field flower resources. Agric Ecosyst Environ. 2020;293:106806.

8. Bennett AB, Lovell S. Landscape and local site variables differentially influence pollinators and pollination services in urban agricultural sites. PloS ONE. 2019;14(2):e0212034.

9. Bentrup G, Hopwood J, Adamson NL, Vaughan M. Temperate agroforestry systems and insect pollinators: a review. Forests. 2019;10(11):981.

10. Berecha G, Aerts R, Muys B, Honnay O. Fragmentation and management of Ethiopian moist evergreen forest drive compositional shifts of insect communities visiting wild Arabica coffee flowers. Environ Manag. 2015;55(2):373-82.

11. Blitzer EJ, Dormann CF, Holzschuh A, Klein A-M, Rand TA, Tscharntke T. Spillover of functionally important organisms between managed and natural habitats. Agric Ecosyst Environ. 2012;146(1):34-43.

12. Boreux V, Krishnan S, Cheppudira KG, Ghazoul J. Impact of forest fragments on bee visits and fruit set in rain-fed and irrigated coffee agroforests. Agric Ecosyst Environ. 2013;172:42-8.

13. Botsch JC, Walter ST, Karubian J, González N, Dobbs EK, Brosi BJ. Impacts of forest fragmentation on orchid bee (Hymenoptera: Apidae: Euglossini) communities in the Chocó biodiversity hotspot of northwest Ecuador. J Insect Conserv. 2017;21(4):633-43.

14. Bravo-Monroy L, Tzanopoulos J, Potts SG. Ecological and social drivers of coffee pollination in Santander, Colombia. Agric Ecosyst Environ. 2015:211:145-54.

15. Breitbach N, Tillmann S, Schleuning M, Grünewald C, Laube I, SteffanDewenter I, Böhning-Gaese K. Influence of habitat complexity and landscape configuration on pollination and seed-dispersal interactions of wild cherry trees. Oecologia. 2012;168(2):425-37. 
16. Briggs $H$, Perfecto I, Brosi B. The role of the agricultural matrix: coffee management and euglossine bee (Hymenoptera: Apidae: Euglossini) communities in southern Mexico. Environ Entomol. 2013;42(6):1210-7.

17. Brosi BJ. The complex responses of social stingless bees (Apidae: Meliponini) to tropical deforestation. For Ecol Manag. 2009;258(9):1830-7

18. Brosi BJ. The effects of forest fragmentation on euglossine bee communities (Hymenoptera: Apidae: Euglossini). Biol Cons. 2009;142(2):414-23.

19. Brosi BJ, Daily GC, Ehrlich PR. Bee community shifts with landscape context in a tropical countryside. Ecol Appl. 2007;17(2):418-30.

20. Brosi BJ, Daily GC, Shih TM, Oviedo F, Durán G. The effects of forest fragmentation on bee communities in tropical countryside. J Appl Ecol. 2008;45(3):773-83.

21. Bruinsma J. The resource outlook to 2050: by how much do land, water and crop yields need to increase by 2050. In: Expert meeting on how to feed the world in. Rome: FAO; 2009. p. 24-6.

22. Buchori D, Rizali A, Larasati A, Hidayat P, Ngo H, Gemmil-Herren B. Natural habitat fragments obscured the distance effect on maintaining the diversity of insect pollinators and crop productivity in tropical agricultural landscapes. Heliyon. 2019;5(3):e01425.

23. Calvillo LM, Ramírez VM, Parra-Tabla V, Navarro J. Bee diversity in a fragmented landscape of the Mexican neotropic. J Insect Conserv. 2010;14(4):323-34.

24. Campbell AJ, Carvalheiro LG, Maués MM, Jaffé R, Giannini TC, Freitas MAB, Coelho BWT, Menezes C. Anthropogenic disturbance of tropical forests threatens pollination services to açaí palm in the Amazon river delta. J Appl Ecol. 2018;55(4):1725-36.

25. Chacoff NP, Aizen MA. Edge effects on flower-visiting insects in grapefruit plantations bordering premontane subtropical forest. J Appl Ecol. 2006:43(1):18-27.

26. Coudrain V, Rittiner S, Herzog F, Tinner W, Entling MH. Landscape distribution of food and nesting sites affect larval diet and nest size, but not abundance of Osmia bicornis. Insect Sci. 2016;23(5):746-53.

27. Crall JD, Brokaw J, Gagliardi SF, Mendenhall CD, Pierce NE, Combes SA Wind drives temporal variation in pollinator visitation in a fragmented tropical forest. Biol Lett. 2020;16(4):20200103.

28. Craven D, Filotas E, Angers V, Messier C. Evaluating resilience of tree communities in fragmented landscapes: linking functional response diversity with landscape connectivity. Divers Distrib. 2016;22(5):505-18.

29. Crossman N, Bernard F, Egoh B, Kalaba F, Lee N, Moolenaar S. The role of ecological restoration and rehabilitation in production landscapes: an enhanced approach to sustainable development, working paper for the UNCCD Global Land Outlook. Paris: UNCCD; 2016.

30. da Rocha-Filho LC, Rabelo LS, Augusto SC, Garófalo CA. Cavity-nesting bees and wasps (Hymenoptera: Aculeata) in a semi-deciduous Atlantic forest fragment immersed in a matrix of agricultural land. J Insect Conserv. 2017:21(4):727-36.

31. De Marco P, Coelho FM. Services performed by the ecosystem: forest remnants influence agricultural cultures' pollination and production. Biodivers Conserv. 2004;13(7):1245-55.

32. Devkota K, dos Santos CF, Blochtein B. Mustard plants distant from forest fragments receive a lower diversity of flower-visiting insects. Basic Appl Ecol. 2020;47:35-43.

33. Du Clos B, Drummond FA, Loftin CS. Noncrop habitat use by wild bees (Hymenoptera: Apoidea) in a mixed-use agricultural landscape. Environ Entomol. 2020;49(2):502-15.

34. Ekroos J, Rundlöf M, Smith HG. Trait-dependent responses of flowervisiting insects to distance to semi-natural grasslands and landscape heterogeneity. Landsc Ecol. 2013;28(7):1283-92.

35. Escobedo-Kenefic N, Landaverde-González P, Theodorou P, Cardona E, Dardón MJ, Martínez O, Domínguez CA. Disentangling the effects of local resources, landscape heterogeneity and climatic seasonality on bee diversity and plant-pollinator networks in tropical highlands. Oecologia. 2020;194(3):333-44.

36. Ewers RM, Bartlam S, Didham RK. Altered species interactions at forest edges: contrasting edge effects on bumble bees and their phoretic mite loads in temperate forest remnants. Insect Conserv Divers. 2013;6(5):598-606.

37. Fahrig L, Baudry J, Brotons L, Burel FG, Crist TO, Fuller RJ, Sirami C, Siriwardena GM, Martin JL. Functional landscape heterogeneity and animal biodiversity in agricultural landscapes. Ecol Lett. 2011;14(2):101-12.
38. Ferreira PA, Boscolo D, Lopes LE, Carvalheiro LG, Biesmeijer JC, da Rocha PLB, Viana BF. Forest and connectivity loss simplify tropical pollination networks. Oecologia. 2020;192(2):577-90.

39. Franceschinelli EV, Elias MA, Bergamini LL, Silva-Neto CM, Sujii ER. Influence of landscape context on the abundance of native bee pollinators in tomato crops in Central Brazil. J Insect Conserv. 2017;21(4):715-26.

40. Frankie G, Thorp R, Hernandez J, Rizzardi M, Ertter B, Pawelek J, Witt S, Schindler M, Coville R, Wojcik V. Native bees are a rich natural resource in urban California gardens. Calif Agric. 2009;63(3):113-20.

41. Gallai N, Salles J-M, Settele J, Vaissière BE. Economic valuation of the vulnerability of world agriculture confronted with pollinator decline. Ecol Econ. 2009:68(3):810-21.

42. García D, Chacoff NP. Scale-dependent effects of habitat fragmentation on hawthorn pollination, frugivory, and seed predation. Conserv Biol. 2007;21(2):400-11.

43. Garibaldi LA, Steffan-Dewenter I, Winfree R, Aizen MA, Bommarco R, Cunningham SA, Kremen C, Carvalheiro LG, Harder LD, Afik O. Wild pollinators enhance fruit set of crops regardless of honey bee abundance. Science. 2013;339(6127):1608-11.

44. Gómez-Martínez C, Aase ALT, Totland Ø, Rodríguez-Pérez J, Birkemoe T, Sverdrup-Thygeson A, Lázaro A. Forest fragmentation modifies the composition of bumblebee communities and modulates their trophic and competitive interactions for pollination. Sci Rep. 2020;10(1):1-15.

45. Gonçalves RB, Sydney NV, Oliveira PS, Artmann NO. Bee and wasp responses to a fragmented landscape in southern Brazil. J Insect Conserv. 2014;18(6):1193-201.

46. Gonzalez-Chaves A, Jaffé R, de Metzger JP, Kleinert AMP. Forest proximity rather than local forest cover affects bee diversity and coffee pollination services. Landsc Ecol. 2020;35(8):1841-55.

47. González-Varo JP, Arroyo J, Aparicio A. Effects of fragmentation on pollinator assemblage, pollen limitation and seed production of Mediterranean myrtle (Myrtus communis). Biol Conserv. 2009;142(5):1058-65.

48. Hermansen TD, Ayre DJ, Minchinton TE. Effects of stand size on pollination in temperate populations of the mangrove Avicennia marina. Plant Ecol. 2014:215(10):1153-62.

49. Hipólito J, Boscolo D, Viana BF. Landscape and crop management strategies to conserve pollination services and increase yields in tropical coffee farms. Agric Ecosyst Environ. 2018;256:218-25.

50. Huais PY, Grilli G, Amarilla LD, Torres C, Fernández L, Galetto L. Forest fragments influence pollination and yield of soybean crops in Chaco landscapes. Basic Appl Ecol. 2020;48:61-72.

51. Jha S, Stefanovich L, Kremen C. Bumble bee pollen use and preference across spatial scales in human-altered landscapes. Ecol Entomol. 2013;38(6):570-9.

52. Joshi NK, Otieno M, Rajotte EG, Fleischer SJ, Biddinger DJ. Proximity to woodland and landscape structure drives pollinator visitation in apple orchard ecosystem. Front Ecol Evol. 2016;4:38.

53. Jules ES, Rathcke BJ. Mechanisms of reduced Trillium recruitment along edges of old-growth forest fragments. Conserv Biol. 1999;13(4):784-93.

54. Keenan RJ, Reams GA, Achard F, de Freitas JV, Grainger A, Lindquist E. Dynamics of global forest area: results from the FAO Global Forest Resources Assessment 2015. For Ecol Manag. 2015;352:9-20.

55. Keitt TH. Habitat conversion, extinction thresholds, and pollination services in agroecosystems. Ecol Appl. 2009;19(6):1561-73.

56. Kim J, Williams N, Kremen C. Effects of cultivation and proximity to natural habitat on ground-nesting native bees in California sunflower fields. J Kansas Entomol Soc. 2006;79(4):309-20.

57. Klein A-M, Vaissiere BE, Cane JH, Steffan-Dewenter I, Cunningham SA, Kremen C, Tscharntke T. Importance of pollinators in changing landscapes for world crops. Proc R Soc B Biol Sci. 2007;274(1608):303-13.

58. Klein AM, Steffan-Dewenter I, Tscharntke T. Pollination of Coffea canephora in relation to local and regional agroforestry management. J Appl Ecol. 2003;40(5):837-45.

59. Klein AM, Steffan-Dewenter I, Tscharntke T. Rain forest promotes trophic interactions and diversity of trap-nesting Hymenoptera in adjacent agroforestry. J Anim Ecol. 2006;75(2):315-23.

60. Kline $\mathrm{O}$, Joshi NK. Mitigating the effects of habitat loss on solitary bees in agricultural ecosystems. Agriculture. 2020;10(4):115.

61. Knoll FDRN, Penatti N. Habitat fragmentation effects on the orchid bee communities in remnant forests of southeastern Brazil. Neotrop Entomol. 2012:41(5):355-65. 
62. Kremen C, Williams NM, Thorp RW. Crop pollination from native bees at risk from agricultural intensification. Proc Natl Acad Sci. 2002;99(26):16812-6.

63. Krishnan S, Kushalappa CG, Shaanker RU, Ghazoul J. Status of pollinators and their efficiency in coffee fruit set in a fragmented landscape mosaic in South India. Basic Appl Ecol. 2012;13(3):277-85.

64. Landaverde-González P, Quezada-Euán JJG, Theodorou P, Murray TE, Husemann M, Ayala R, Moo-Valle H, Vandame R, Paxton RJ. Sweat bees on hot chillies: provision of pollination services by native bees in traditional slash-and-burn agriculture in the Yucatán Peninsula of tropical Mexico. J Appl Ecol. 2017;54(6):1814-24.

65. Landsman AP, Ladin ZS, Gardner D, Bowman JL, Shriver G, D'Amico $\checkmark$, Delaney DA. Local landscapes and microhabitat characteristics are important determinants of urban-suburban forest bee communities. Ecosphere. 2019;10(10):e02908.

66. Lázaro A, Fuster F, Alomar D, Totland $\varnothing$. Disentangling direct and indirect effects of habitat fragmentation on wild plants' pollinator visits and seed production. Ecol Appl. 2020;30(5):e02099.

67. Lonsdorf E, Kremen C, Ricketts T, Winfree R, Williams N, Greenleaf S. Modelling pollination services across agricultural landscapes. Ann Bot. 2009;103(9):1589-600.

68. Lopes LE, Buzato S. Variation in pollinator assemblages in a fragmented landscape and its effects on reproductive stages of a self-incompatible treelet, Psychotria suterella (Rubiaceae). Oecologia. 2007;154(2):305-14.

69. Martins KT, Gonzalez A, Lechowicz MJ. Pollination services are mediated by bee functional diversity and landscape context. Agric Ecosyst Environ. 2015:200:12-20.

70. Maurer C, Bosco L, Klaus E, Cushman SA, Arlettaz R, Jacot A. Habitat amount mediates the effect of fragmentation on a pollinator's reproductive performance, but not on its foraging behaviour. Oecologia. 2020. https://doi.org/10.1007/s00442-020-04658-0.

71. Mayes DM, Bhatta C, Shi D, Brown J, Smith D. Body size influences stingless bee (Hymenoptera: Apidae) communities across a range of deforestation levels in Rondônia, Brazil. J Insect Sci. 2019;19(2):23.

72. Miljanic AS, Loy X, Gruenewald DL, Dobbs EK, Gottlieb IG, Fletcher RJ, Brosi BJ. Bee communities in forestry production landscapes: interactive effects of local-level management and landscape context. Landsc Ecol. 2019;34(5):1015-32.

73. Mitchell M. The effects of landscape structure and biodiversity on ecosystem services. McGill: McGill University Libraries; 2014

74. Mitchell MG, Bennett EM, Gonzalez A. Linking landscape connectivity and ecosystem service provision: current knowledge and research gaps. Ecosystems. 2013;16(5):894-908.

75. Mitchell MG, Bennett EM, Gonzalez A. Strong and nonlinear effects of fragmentation on ecosystem service provision at multiple scales. Environ Res Lett. 2015;10(9):094014.

76. Mola JM, Miller MR, O'Rourke SM, Williams NM. Forests do not limit bumble bee foraging movements in a montane meadow complex. Ecol Entomol. 2020;45(5):955-65.

77. Monasterolo M, Musicante ML, Valladares GR, Salvo A. Soybean crops may benefit from forest pollinators. Agric Ecosyst Environ. 2015;202:217-22

78. Murren CJ. Effects of habitat fragmentation on pollination: pollinators, pollinia viability and reproductive success. J Ecol. 2002;90(1):100-7.

79. Nemésio A, Silveira FA. Forest fragments with larger core areas better sustain diverse orchid bee faunas (Hymenoptera: Apidae: Euglossina). Neotrop Entomol. 2010;39(4):555-61.

80. Nery LS, Takata JT, de Camargo BB, Chaves AM, Ferreira PA, Boscolo D. Bee diversity responses to forest and open areas in heterogeneous Atlantic Forest. Sociobiology. 2018;65(4):686-95.

81. Ollerton J, Winfree R, Tarrant S. How many flowering plants are pollinated by animals? Oikos. 2011;120(3):321-6.

82. Olotu MI, Ndangalasi HJ, Nyundo BA. Effects of forest fragmentation on pollination of Mesogyne insignis (Moraceae) in Amani Nature Reserve forests, Tanzania. Afr J Ecol. 2012;50(1):109-16.

83. Olsson O, Bolin A, Smith HG, Lonsdorf EV. Modeling pollinating bee visitation rates in heterogeneous landscapes from foraging theory. Ecol Model. 2015;316:133-43.

84. Olsson O, Brown JS, Helf KL. A guide to central place effects in foraging. Theor Popul Biol. 2008;74(1):22-33.
85. Pavageau C, Gaucherel C, Garcia C, Ghazoul J. Nesting sites of giant honeybees modulated by landscape patterns. J Appl Ecol. 2018:55(3):1230-40.

86. Perillo LN, de Ulhôa Barbosa NP, Solar RR, de Siqueira Neves F. Patterns of diversity in a metacommunity of bees and wasps of relictual mountainous forest fragments. J Insect Conserv. 2020;24(1):17-34.

87. Potts SG, Biesmeijer JC, Kremen C, Neumann P, Schweiger O, Kunin WE. Global pollinator declines: trends, impacts and drivers. Trends Ecol Evol. 2010:25(6):345-53.

88. Potts SG, Imperatriz-Fonseca V, Ngo HT, Aizen MA, Biesmeijer JC, Breeze TD, Dicks LV, Garibaldi LA, Hill R, Settele J. Safeguarding pollinators and their values to human well-being. Nature. 2016;540(7632):220-9.

89. Rahimi E, Barghjelveh S, Dong P. Estimating landscape structure effects on pollination for management of agricultural landscapes. Ecol Process. 2021;10:59. https://doi.org/10.1186/ s13717-021-00331-3.

90. Rahimi E, Barghjelveh S, Dong P. How effective are artificial nests in attracting bees? A review. J Ecol Environ. 2021;45(1):1-11.

91. Rahimi E, Barghjelveh S, Dong P. Using the Lonsdorf model for estimating habitat loss and fragmentation effects on pollination service. Ecol Process. 2021;10(1):1-13.

92. Rahimi E, Barghjelveh S, Dong P, Pirlar MA, Jahanbakhshian MM. PollMap: a software for crop pollination mapping in agricultural landscapes. J Ecol Environ. 2021:45(1):1-9.

93. Ricketts $\mathrm{TH}$. Tropical forest fragments enhance pollinator activity in nearby coffee crops. Conserv Biol. 2004;18(5):1262-71.

94. Ricketts TH, Regetz J, Steffan-Dewenter I, Cunningham SA, Kremen C, Bogdanski A, Gemmill-Herren B, Greenleaf SS, Klein AM, Mayfield MM Landscape effects on crop pollination services: are there general patterns? Ecol Lett. 2008;11(5):499-515.

95. Ricketts TH, Williams NM, Mayfield MM. Connectivity and ecosystem services: crop pollination in agricultural landscapes. Cambridge: Cambridge University Press; 2006.

96. Rocha-Santos L, Mayfield MM, Lopes AV, Pessoa MS, Talora DC, Faria $D$, Cazetta E. The loss of functional diversity: a detrimental influence of landscape-scale deforestation on tree reproductive traits. J Ecol. 2020;108(1):212-23.

97. Romero MJ, Quezada-Euán JJG. Pollinators in biofuel agricultural systems: the diversity and performance of bees (Hymenoptera: Apoidea) on Jatropha curcas in Mexico. Apidologie. 2013;44(4):419-29.

98. Rosa JF, Ramalho M, Arias MC. Functional connectivity and genetic diversity of Eulaema atleticana (Apidae, Euglossina) in the Brazilian Atlantic Forest Corridor: assessment of gene flow. Biotropica. 2016;48(4):509-17.

99. Ruiz-Toledo J, Vandame R, Penilla-Navarro P, Gómez J, Sánchez D. Seasonal abundance and diversity of native bees in a patchy agricultural landscape in Southern Mexico. Agric Ecosyst Environ. 2020;292:106807.

100. Sande SO, Crewe RM, Raina SK, Nicolson SW, Gordon I. Proximity to a forest leads to higher honey yield: another reason to conserve. Biol Cons. 2009:142(11):2703-9.

101. Saturni FT, Jaffe R, Metzger JP. Landscape structure influences bee community and coffee pollination at different spatial scales. Agric Ecosyst Environ. 2016;235:1-12.

102. Silva D, Nogueira D, De Marco P. Contrasting patterns in solitary and eusocial bees while responding to landscape features in the Brazilian Cerrado: a multiscaled perspective. Neotrop Entomol. 2017:46(3):264-74.

103. Silva DP, De Marco P. No evidence of habitat loss affecting the orchid bees Eulaema nigrita Lepeletier and Eufriesea auriceps Friese (Apidae: Euglossini) in the Brazilian Cerrado Savanna. Neotrop Entomol. 2014:43(6):509-18.

104. Silva M, Ramalho M, Monteiro D. Communities of social bees (Apidae: Meliponini) in trap-nests: the spatial dynamics of reproduction in an area of Atlantic Forest. Neotrop Entomol. 2014;43(4):307-13.

105. Silva S, Almeida N, de Siqueira K, Souza J, Castro C. Isolation from natural habitat reduces yield and quality of passion fruit. Plant Biol. 2019;21(1):142-9.

106. Smith TJ, Mayfield MM. The effect of habitat fragmentation on the bee visitor assemblages of three Australian tropical rainforest tree species. Ecol Evol. 2018:8(16):8204-16. 
107. Sober V, Leps M, Kaasik A, Mänd M, Teder T. Forest proximity supports bumblebee species richness and abundance in hemi-boreal agricultural landscape. Agric Ecosyst Environ. 2020;298:106961.

108. Sritongchuay T, Hughes AC, Memmott J, Bumrungsri S. Forest proximity and lowland mosaic increase robustness of tropical pollination networks in mixed fruit orchards. Landsc Urban Plan. 2019;192:103646.

109. Sritongchuay T, Kremen C, Bumrungsri S. Effects of forest and cave proximity on fruit set of tree crops in tropical orchards in Southern Thailand. J Trop Ecol. 2016;32(4):269-79.

110. Stangler ES, Hanson PE, Steffan-Dewenter I. Vertical diversity patterns and biotic interactions of trap-nesting bees along a fragmentation gradient of small secondary rainforest remnants. Apidologie. 2016:47(4):527-38.

111. Steffan-Dewenter I, Münzenberg U, Bürger C, Thies C, Tscharntke T. Scale-dependent effects of landscape context on three pollinator guilds. Ecology. 2002;83(5):1421-32.

112. Steffan-Dewenter I, Schiele S. Do resources or natural enemies drive bee population dynamics in fragmented habitats. Ecology. 2008:89(5):1375-87.

113. Storck-Tonon D, Peres CA. Forest patch isolation drives local extinctions of Amazonian orchid bees in a 26 years old archipelago. Biol Conserv. 2017:214:270-7

114. Suarez-Gonzalez A, Good SV. Pollen limitation and reduced reproductive success are associated with local genetic effects in Prunus virginiana, a widely distributed self-incompatible shrub. Ann Bot. 2014;113(4):595-605.

115. Sugiura S, Taki H. Scale-dependent effects of habitat area on species interaction networks: invasive species alter relationships. BMC Ecol. 2012;12(1):1-13.

116. Syrbe R-U, Walz U. Spatial indicators for the assessment of ecosystem services: providing, benefiting and connecting areas and landscape metrics. Ecol Ind. 2012;21:80-8.

117. Taki H, Kevan PG, Ascher JS. Landscape effects of forest loss in a pollination system. Landsc Ecol. 2007;22(10):1575-87.

118. Taki H, Murao R, Mitai K, Yamaura Y. The species richness/abundancearea relationship of bees in an early successional tree plantation. Basic Appl Ecol. 2018;26:64-70.

119. Taki H, Yamaura Y, Okabe K, Maeto K. Plantation vs. natural forest: matrix quality determines pollinator abundance in crop fields. Sci Rep. 2011;1(1):1-4

120. Tonhasca A Jr, Albuquerque GS, Blackmer JL. Dispersal of euglossine bees between fragments of the Brazilian Atlantic Forest. J Trop Ecol. 2003. https://doi.org/10.1017/S0266467403003122.

121. Tylianakis JM, Klein AM, Lozada T, Tscharntke T. Spatial scale of observation affects $a, \beta$ and $\gamma$ diversity of cavity-nesting bees and wasps across a tropical land-use gradient. J Biogeogr. 2006;33(7):1295-304.

122. Valdovinos FS, Chiappa E, Simonetti JA. Nestedness of bee assemblages in an endemic South American forest: the role of pine matrix and small fragments. J Insect Conserv. 2009;13(4):449-52.

123. Viana BF, Boscolo D, Mariano Neto E, Lopes LE, Lopes AV, Ferreira PA, Pigozzo CM, Primo LM. How well do we understand landscape effects on pollinators and pollination services? J Pollinat Ecol. 2012. https://doi. org/10.26786/1920-7603(2012)2

124. Vides-Borrell E, Porter-Bolland L, Ferguson BG, Gasselin P, Vaca R, ValleMora J, Vandame R. Polycultures, pastures and monocultures: effects of land use intensity on wild bee diversity in tropical landscapes of southeastern Mexico. Biol Conserv. 2019;236:269-80.

125. Wayo K, Sritongchuay T, Chuttong B, Attasopa K, Bumrungsri S. Local and landscape compositions influence stingless bee communities and pollination networks in tropical mixed fruit orchards, Thailand. Diversity. 2020;12(12):482.

126. Williams NM, Kremen C. Resource distributions among habitats determine solitary bee offspring production in a mosaic landscape. Ecol Appl. 2007;17(3):910-21.

127. Willmer PG, Cunnold H, Ballantyne G. Insights from measuring pollen deposition: quantifying the pre-eminence of bees as flower visitors and effective pollinators. Arthropod Plant Interact. 2017;11(3):411-25.

128. Winfree R, Williams NM, Gaines H, Ascher JS, Kremen C. Wild bee pollinators provide the majority of crop visitation across land-use gradients in New Jersey and Pennsylvania, USA. J Appl Ecol. 2008;45(3):793-802.
129. Wray JC, Neame LA, Elle E. Floral resources, body size, and surrounding landscape influence bee community assemblages in oak-savannah fragments. Ecol Entomol. 2014;39(1):83-93.

130. Zimmermann Y, Schorkopf D, Moritz R, Pemberton R, Quezada-Euan J, Eltz T. Population genetic structure of orchid bees (Euglossini) in anthropogenically altered landscapes. Conserv Genet. 2011;12(5):1183-94.

131. Zurbuchen A, Bachofen C, Müller A, Hein S, Dorn S. Are landscape structures insurmountable barriers for foraging bees? A markrecapture study with two solitary pollen specialist species. Apidologie. 2010;41(4):497-508.

132. Zurbuchen A, Landert L, Klaiber J, Müller A, Hein S, Dorn S. Maximum foraging ranges in solitary bees: only few individuals have the capability to cover long foraging distances. Biol Cons. 2010;143(3):669-76.

\section{Publisher's Note}

Springer Nature remains neutral with regard to jurisdictional claims in published maps and institutional affiliations.
Ready to submit your research? Choose BMC and benefit from:

- fast, convenient online submission

- thorough peer review by experienced researchers in your field

- rapid publication on acceptance

- support for research data, including large and complex data types

- gold Open Access which fosters wider collaboration and increased citations

- maximum visibility for your research: over $100 \mathrm{M}$ website views per year

At BMC, research is always in progress.

Learn more biomedcentral.com/submissions 